\title{
DEIXIS FOUND IN MOVIE SCRIPT SING
}

\author{
Ni Made Dwipayani \\ Universitas Warmadewa \\ dwipayani14@gmail.com \\ I Ketut Subagia \\ Universitas Warmadewa \\ subagia35@yahoo.com \\ Anak Agung Gede Suarjaya \\ Universitas Warmadewa \\ mynsuar@gmail.com
}

\begin{abstract}
The title of this paper is Deixis found in Movie Script Sing. In this paper, the writers try to analyze and discuss about the type, class words, and the use of deixis found in the movie script Sing. Data were collected from the movie script of Sing. The data were classified based on the types to Levinson's Theory (1983). The specific aim of this paper is to describe and analyze the types of deixis in the movie script, analyze sentence by sentence. By doing this research it will be able to know more details about the types of deixis. Then analyzed, it was the types, class words and the use of deixis in the movie Sing. In collecting the data, observation method was applied. First the writer watched the movie than observed the subtitle in the movie. Then were quoted the selected data, and classified in accordance with their types of deixis. Based on the result of analysis, it was found there are five types of deixis, namely person deixis (including I, my, me, she, her, his, she, he, we, you, they), time deixis (including now), place deixis (including here), discourse deixis (including this, that), and social deixis (including mommy and grandpa).
\end{abstract}

Keywords: deixis; movie; scrip sing

\section{INTRODUCTION}

In studying language the use of word, phrase, or any expression often refers to any others depend on who is speaking, the time and the place where the word is used. For knowing the real meaning of that expression we should study about deixis. Deixis means knowing the meaning of words and phrases in an utterance. Besides, deixis also relates to the context of the utterance, like the speaker, the time, and the place of speaking. Besides, the gesture of the speaker, the current location, and the topic is very important in deixis. Every information uttered by speakers refers to different things. The meaning refers to person, place and time. According to Lyons (1977: 637) deixis is the location and identification of people, object, events, process, and activities which is being talked about or referred to in relation to time, when the speaker says the utterance, or when the hearer hears it (Lyons, 1977) Saeed states that semantics is the study of meaning communicated through language (Saeed, 2000). Relation to the meaning, Leech (1981) states there are seven types of meaning namely conceptual, connotative, social, affective, reflected, collective, and thematic meaning (Leech, 1981). Although language is used to communicate, sometimes the utterances delivered by speaker to the hearer or addressee are ambiguous. Deixis is part of pragmatic which is studying about how the transmission of meaning depends not only on structural and also linguistic knowledge of the speaker and listener but also the context of the utterance.

In this writing it needs to make more specific in its analysis. The problem which needs to be discussed related to the topic is 
deixis found in the Sing movie script. The problem is formulated in the following questions: (1) what types of deixis are found in Sing movie script? (2) what class of words is used to express it in Sing movie script? And (3) how are they used?

This paper is to build up and develop our ability about the uses of English in movie. However, in this case the writers try to analyze types of deixis. The specific aim of this paper is to describe and analyze the types and the word classes of deixis in the movie script, analyze sentence by sentence. By doing this research writers know more details about the types and the word classes of deixis.

The main theory used in this study is a book written by George Yule in 1995 entitled Pragmatics. She states that: deictic expression is of two parts. They are proximal and distal terms.

Proximal terms are known near from the speaker, the terms are "This, here, now". Whereas, distal term is known away from the speaker, it includes "That, there and then". Therefore, deixis is the signifier used for identifying people, object, event, process or an activity that is being spoken or referred into time. (Yule, 1995: 9).

Besides the main theory above, another theory is also used as supporting theory. It is a book about deixis written by Stephen C Levinson 1983 entitled Pragmatics, he said that:

Deixis concern the ways in which language encode or grammaticalize features of the context of utterance or speech event, and thus also concern ways in which the interpretations of utterances depends on the analysis of that context of utterance, (Levinson, 1983: 54).

\section{METHOD}

The methods of research give some guidance to understand the object being observed. The method as a way of working must be described according to the tool or the nature of the tool used. The description such method is called procedure (Sudaryanto, 1986). The methods of research applied in this paper can be divided into three. They are in determining data source, in collecting data, in analyzing, and in presenting the result. They can be described as follows.

The data were taken from the script of movie Sing is a 2016 United States 3D computer animated musical comedy produced by Illumination entertainment and this movie script was written by Garth Jennings and directed by Garth Jennings too and star voices of Matthew McConaughey, Reese Witherspoon, Seth MacFarlane, Scarlett Johnsson, John C. Reilly, Taron Egerton and Tori Kelly. The movie details tell the story of a group of animals who are members of the singing contest, guided by koalas who hope to save his theater. This movie script was chosen as the source of the study because it provides the supported data for the study. Besides, Sing movie also contains many utterances in the dialogue, and many gestures and pointing in kid movie.

Data collection is the systematic approach to gathering and measuring information from a variety of source. Observation method is used in collecting data

The way of analyzing data can be briefly explained as follows: identifying types of deixis used by the characters in the utterance, classification the usage of the deixis by the characters into types of deixis namely: person deixis, time deixis, place deixis, discourse deixis and social deixis, analysis the context of the utterances, description the usage of deixis by the characters and the referent of the deixis and making conclusion. It means that in analyzing the data, I use descriptive method.

Presenting the result of the analysis is the final step after analyzing the data based on their types. The informal method is used to describe and explain the result of the analysis. Informal means presentation by using ordinary word (Sudaryanto, 1986). By this way, all explanations about deixis could be easy to understand.

\section{DISCUSSION \\ Deixis Found in Movie Script Sing}

This chapter analyzes the Sing movie script by applying the deixis analysis. Most of the meaning only can be understood by looking at linguistics markers, to pointing a specific thing, without knowing who is the addressee, when does it happen, and location of the conversation 
take a place, to make sure we interpret a correct meaning, those terms that we cannot interpret without an immediate context is sometimes called deixis which means pointing.

Kreidler (1998: 144) states that every utterance has deixis words which 'point' to 'things' in the physical social context of the speaker and addressee (s) and whose referents can only be determined by knowing the context in which they are used (Kreidler, 1998: 144) . The categories of deixis can be divided into five types. They are person deixis, spatial deixis, temporal deixis, social deixis, and discourse deixis. Person deixis is about the use of personal pronouns, spatial deixis as in the use of demonstrative and adverb, temporal or time deixis as in the encoding of adverb of time, discourse deixis which has reference to textual and situational context, and also social deixis as in the encoding of social relationship among the people. The data were used to analyze types of deixis in this paper were taken from the movie script of Sing. The data were analyzed just representative data or type deixis which were found in the movie.

1. Person Deixis

This deixis is an expression to know or refer to someone or person who speaker intends refer. Person deixis is used to encoding the role of the participants in certain conversation. First and second person pronouns refer to the speaking and hearing speech participants, whereas third person pronouns designate the non-speech or narrated participant. It is reflected directly to grammatical categories of person.

In the movie script of Sing was found three types of person deixis. Those are first, second, and third person. First person consist of singular and plural pronoun. Second person consist of singular personal pronoun and the third person deixis consist of singular and plural of the third person deixis.

\section{a. First Person Deixis}

First person deixis can be classified into two different types they are first person singular and first person plural. The analysis can be seen below.

a) First Person Singular
All the data in this section can be classified into first person singular. The analysis can be seen below.

First Person Singular "I"

First person singular $I$, based on its forms, is classified as subject pronouns. The data and the analysis can be seen in the section below:

(1) Buster : Holy Moly, I really do.

Miss Crawly : Yah, it's the stage crew from your last show. They say their pay checks bounced and-(00:09:45)

(2) Miss Crawly : Oh. What should I tell her this time?

Buster : Tell her Buster Moon is out to lunch! (00:10:34)

(3) Police Rhino : Huh. Thought $I$ heard someone singin there. Ah, whatever.

Johnny : Guys! Listen! Stay where you are! The cops are here and (00:05:54)

(4) Buster : There we go. Now, $\boldsymbol{I}$ need you to add the following information to our publicity flyers.

Miss Crawly : Yes sir

Buster : The winner of the singing contest will receive a grand prize on Nine hundred and thirty five dollars, hmmm gonna need more that that, just a second. (00:23:34)

In the first data, the conversation is between Buster and Miss Crawly. The word $I$ that is used in the first conversation belongs to deixis. $I$ can refer to someone, but in this context $I$ refers to Buster. The situation is about Buster want to make his dream come true. He makes a singing competition at his own theatre, Moon Theatre. He discusses about the show with his secretary Miss Crawly. Therefore, the word $I$ can be categorized as first person singular deixis.

In data (2), the situation is when Buster grabs a briefcase and dashes across the room. A group of angry animals waiting and pacing in the hall 
outside his office and they were knocking and shouting continuous from outside. Buster moves a large of poster to reveal a small hole in the wall. After that, Miss Crawly came to the office and she tells to Buster "What should I tell her this time". The word I that is used in the conversation belongs to deixis. In data (1) I refers to Buster, but in data (2) $I$ refers to Miss Crawly because this question sentence is asked by Miss Crawly. In this data I can also be categorized as person singular deixis.

In data (3) the conversation is between Johnny and Police Rhino. The situations are around the corner is looked by Johnny: in his direction two police Rhinos are strolling. Johnny gasps as he ducks back into the shadows of the alley just as the COPS appear mildly curious. Police Rhino told his friends "Huh thought I heard someone singin there". The word $I$ here belongs to deixis. In data (1) I refers to Buster, in data (2) $I$ refers to Miss Crawly but in this context the word $I$ refers to Police Rhino as the speaker. Therefore, the word $I$ can be categorized as first person singular deixis.

In data (4), the conversation above is between Buster and Miss Crawly they are talking about publicity flyers and grand prize. Buster grab to the money box to take money and unplugs it with an old radio in the other box, and he rolls up a small Persian hug, takes off his watch. Buster hurls all of the boxes and put it into a prop chest and closes the lid. Buster makes conversation like in the data (4). In the conversation above the word $I$ belongs to deixis. In data (1) I refers to Buster, in data (2) $I$ refers to Miss Crawly and in data (3) I refers to Police Rhino, but in this context $I$ refers to Buster as the speaker. The word $I$ also can be categorized as singular first person deixis.

First Person Singular "ME"
In the data, beside first person $I$, there is also first person "ME", it is classified as object in the sentence. The analysis can be seen below.

(1) Richard : Urgh! What is wrong with $\boldsymbol{m e}$ ?

Buster : Phew. Um, thanks for coming Richard. (00:09:23)

(2) Buster : Daniel? Can you hear $\boldsymbol{m} \boldsymbol{e}$ ? You're in the show! Daniel : What? Are you talking to $\boldsymbol{m} \boldsymbol{e}$ ? (00:17:45)

(3) Rosita : Wait, you want us to sing together?

Gunter : Ja! The two of us together, are you joking $\boldsymbol{m e}$ ? We're going to be spicy, no Hahaha (00:32:12)

In data (1) the conversation is between Richard and Buster. The situation is when Buster circles them, checks them up and down from behind and Richard is so nervous that he suddenly farts. The word $m e$ in the conversation (1) is spoken by Richard, Richard is the first speaker at the event. The word $m e$ in the conversation belongs to deixis. me can refers to someone, but in this context me refers to Richard. Then it can be categorized as singular first person deixis.

In the data (2) the conversation is between Buster and Daniel. The situation is when Johnny leaves the stage and sadly in agreement with the decisions. But Daniel has responded. The word $m e$ in conversation (2) is spoken by Buster and also by Daniel. The word $m e$ in the conversation belongs to deixis, me can refer to someone, so in the first sentence of data (2) me refers to Buster and in the second sentence me refers to Daniel. Therefore, it can be categorized as first person singular.

In data (3) the conversation is between Rosita and Gunter. The situation is when Rosita step forward. Gunter is in freestyles to across the stage to Join Rosita. Buster wants Rosita and Gunter singing together at 
the show. The word me in the conversation belongs to deixis. The word me in data (1) refers to Richard, in data (2) refers to Buster and Daniel, but in this context me refers to Gunter as the speaker. Therefore, it is categorized as first person singular.

First Person Singular "MY"

First person singular my it is classified possessive adjectives is also found in the data script, the analysis can be seen below.

(1) Buster : Okay, that's everyone on $\boldsymbol{m} \boldsymbol{y}$ list. Umm... wait a second. Rosita, is Rosita still here?

Rosita : Yes! Yes, I'm here! (00:45:15).

(2) Big Daddy : There he is! I got a surprise for you, my son. Hahaha...

Johnny : What's that? (00:31:12).

In data (1) the conversation is between Rosita and Buster. Buster takes of the winner list of the contest from Miss Crawly. He checks the entire list and finds Rosita's name. The word $m y$ is found in conversation (1) above belongs to deixis, my showed an ownership of the first speaker. The word $m y$ in the conversation refers to Buster, therefore the word my can be classified as first person singular.

In data (2) the conversation is between Big Daddy and Johnny. Through the door Johnny walks. Around a model plan of a robbery the gang has gathered. The word my belongs to deixis. Big Daddy is the first speaker and he said my son and it showed his ownership, so the word $m y$ refers to Big Daddy. And the pronoun $m y$ can be categorized as first person singular.

b) First Person Plural

Besides first person singular, there is also first person plural found in the movie. In English there is only one first person plural, it is we. Based on the data, first person plural we is classified as subject pronouns. When "WE" talk about ourselves, our opinion and the things happen to us, we generally speak in the first person. The analysis can be seen in following discussion.

First Person Plural "WE"

(1) Bull : Alright look Eddie : Can we please just get outta here?

Buster : Don't you
wanna eat? (00:54:12).

(2) Buster : Print em up on every single sheet of paper we have left. And let's spread the word right away, okay?

Miss Crawly : Yes, oh yes sir! (01:12:23).

(3) Buster : How we doing with those flyers Miss Crawly?

Miss Crawly : Oh yes, sir, we're all good to go here (00:28:45).

(4) Ash : Ha ha very funny Buster : Loud and horrible but shows promise. Welcome to the show

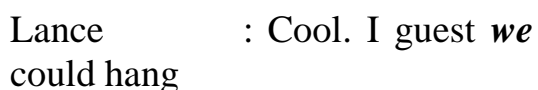
Buster : No, no, I just want her. Not you (00:48:31).

In data (1) it is found that, Buster pounds his fist, catapulting his spoon across the room where it knocks into a Bull, who drops his cell phone into his soup. The conversation is between Buster, Eddie and Bull. The dialogue in data (1) above contains into first person deixis. The word we belongs to deixis. Especially, it can be said as plural pronoun of first person because it refers to more than one person. The speaker in the text above is Eddie, when he said the word we it refers to him and his friend Bull. The word we in the conversation above can be classified as exclusive we because it refers not only the speaker but also other people.

In data (2) the conversation is take a place in the Buster's office. Miss Crawly causes her glass eye to pop out. It bounces on the keyboard, adding 2 more zeros to the prize money. 1000 becomes 100,000. Eye glass of Miss Crawly rolls across the floor and under 
the piano. She hits the print and gets up to go fetch her glass eye. The word we used in conversation (2) belongs to deixis. In the dialogue above Buster is as the speaker spoke the word we. In data (1) the word we refers to Eddie and his friends Bull, but in this context the word we refers to Buster and his secretary Miss Crawly. It could be categorized as plural first person and also it can be classified as exclusive we, because it refers not only the speaker but also other people.

In data (3) the conversation takes place in the Buster's office. The situations are when Buster takes a deep breath after walking over the window and, looks out at the city below. Under his paw a little wood and paint crumbles. Buster opens the door into Miss Crawly's room. Miss Crawly turns from the printer with her arms full of flyers. The word we belongs to deixis. In the data (1) we refers to Buster and his friends Bull and Eddie, in data (2) we refers to Buster and Miss Crawly but in this dialogue Buster as the speaker spoke the word we. The word we refers to him and his secretary Miss Crawly. It could be categorized as plural first person and also it can be classified as exclusive we because it refers not only the speaker but also other people.

In data (4) the conversation takes place in the Moon Theatre. The situation is when before the huge crowd of animals Buster stands, a tremendous presence for such a tiny ball of fur. Each animal is checked by Buster in painful silence. He selects the frog and rejects most of them.. The frogs celebrate Buster turns to Ash and Lance. The word we in data (4) belongs to deixis. In the dialogue above Lance as the speaker spoke the word we, the word we refers to him, his friends Ash and Buster. It could be categorized as first person plural and also it can be classified as exclusive "we" because it refers not only the speaker but also other people. b. Second Person Deixis

Person deixis refers to people (Lyons, 1974: 276). In the data source, beside first person deixis, second person deixis is also found in the data source, the following analysis can be seen below.

Second Person Deixis "YOU"

The example of the use of deixis "you" can be seen in the following utterances:

(1) Big Daddy : Johnny! You were supposed to be keeping a lookout!

Johnny : Sorry Dad (00:31:45).

(2) Meena : Uh... okay, uh... Buster : Anytime now... Meena :Hmmm...

Buster : Do you wanna start over? (00:37:11).

(3) Grandpa : Come on, don't you want this?

Meena : Well, sure, but I messed it up (00:42:14).

(4) Miss Crawly: ARRGH! Johnny, Oh you, you gave me a fright there.

Johnny : Sorry, I didn't mean to, I just well, I know it's late but, well I could really use some extra piano lessons (01:29:54).

In data (1) the conversation is about Big Daddy and Johnny. The Gorilas dash out of sight down a perpendicular alley way after seeing the cops. The cops is still hiding in the shadows and charging past Johnny, but they are forced back against the charges right past them. As the trucks pass Johnny, he leaps on to the back where the two other Gorillas' cling to their loot. The leader (Big Daddy) commands with fierce authority. The word you belongs to deixis. The word you in the conversation is one of deictic marker that includes into second person deixis, the word you spoken by Big Daddy it refers to Johnny. Therefore the word you in the conversation can be classified as subject pronouns.

In data (2) the conversation is between Buster and Meena. The 
backing track for "Chandelier" by Sia begins to play but Meena only Stutters are nervously. Buster feels bad for her. The word "you" belongs to deixis. The word you found at the conversation above can be classified as subject pronouns, and it spoken by Buster.in data (1) the word you is refers to Johnny, but in this context the word you refers to Meena. The word you in the conversation above can be classified as second person deixis.

In data (3) the conversation is between Meena and Grandpa. The conversation takes place at Meena's kitchen. Meena is sitting at the kitchen table, tears rolling down her cheecks as she whisks a bowl of batter. Grandpa preaches from the doorway. The word you belongs to deixis. In data (1) you refers to Johnny and in data (2) you refers to Meena but in this context the word you in the conversation is spoken by Grandpa as the speaker. The word you in the conversation refers to Meena as the second speaker, therefore the word you categorized as second person deixis and also it can be classified as subject pronouns.

In data (4) the conversation is between Miss Crawly and Johnny. The conversation takes place at Moon Theatre. The word you belongs to deixis. In data (1) you refers to Johnny, in data (2) you refers to Meena and in data (3) you refers to Meena but in this context the word you is spoken by Miss Crawly as the speaker and the word you refer to Johnny as the second person in the conversation above. The word you found in the conversation categorized as subject pronoun and also it is categorized as second person deixis.

c. Third Person Deixis

In the data source, beside first person and second person, it also found third person deixis. Third person can be classified into two types they are singular and plural.

a) Third Person Singular

Third Person Singular "HE"
Third person singular he is classified as third person singular subject, the example of the use of deixis hecan be seen in the following utterances:

(1) Buster : And as you can see, this is no ordinary theatre! This is a palace of wonder and magic

Eddie

: $\boldsymbol{H e}$ is done it! $\mathrm{He}$

is really done it, Nana!

Nana : Ohh goodness (01:06:34).

(2) Boss Bear : Right, Mike here says you got his money and it's in that box

Buster : No no no no, just hold on a moment here! That's prize money and it's not Mike's unless $\boldsymbol{h} \boldsymbol{e}$ wins it fair and(00:37:12).

In data (1), the conversation is between Buster, Eddie and Nana. Suddenly hundred of squid light up at the underwater stage as the beat of flashing light kicks in. it's like liquid fireworks. The squid move and change color in perfect synchronization with the music. A dazzling sight. Buster dances and the squid trace his steps. The word he belongs to deixis. In the conversation above the word he spoken by Eddie. The word he in the conversation refers to Buster. Therefore, the word he can be categorized as third person deixis.

In data (2), the conversation is between Boss Bear and Buster. The auditorium door flies open revealing three bears. The bears hold up mike by the throat. The word he belongs to deixis. In the conversation (2) the word $h e$ is spoken by Buster. The word he in the conversation above is expression of deixis because it refers to a person out of the conversation, it indicates that the referent pointed to one person that did not exist when the conversation begins, the word he in the conversation refers to Mike, therefore the word he can be categorized as third person deixis.

Third Person Singular "SHE" 
Third person singular she is classified as third person singular subject.

The example of the use of deixis she can be seen in the following utterances:

(1) Grandma : Oh, here she is! Quiet down everybody. Shh!

Grandpa : So, Meena? Are you in the show? (00:56:52).

(2) Grandpa : Wooooo-hooo!

She did it!

Meena's Mother : Aaaahhh! I

knew it! I knew it! (00:58:12).

(3) Miss Crawly : I have Judith

from the bank

Buster : Whaa, no no no, tell her, I'll call her back in the morning

Miss Crawly : Oh, I can't. She

is right here (00:18:29).

(4) Nana : Oh, Lucky me. A

visit from my useless grandson and his little theatre friend

Buster : Look at that, she remembers me. Okay Nana, how would you like to be the sponsor for a very prestigious prize? (00:44:42).

In data (1) the event happens in Meena's house. The conversation is between

Grandpa and Grandma. The word "she" belongs to deixis. The word she in the conversation (1) is a deictic expression because it refers to a person out of the conversation, it indicates that the referent pointed to one person that did not exist when the conversation begins. The word she spoken by Grandma is refers to Meena, therefore the word she can be categorized as third person deixis

Data (2) contains the situations when explosion od cheers from the crowd. Meena turns to her moher. The conversation is between Grandpa and Meena's mother. The word she belongs to deixis. The word "she" in the conversation above is deictic expression because it refers to a person that did not exist when the conversation begins. In data (1) she refers to Meena but in this context the word she is spoken by Grandpa is refers to Meena, therefore the word she can be categorized as third person deixis.

In data (3) the event happens in Buster office. The word she belongs to deixis. The word she in the conversation above is deictic expression because it refers to a person that did not exist when the conversation begins. In data (1) she refers to Meena and in data (2) she refers to Meena to but in this context the word she is spoken by Miss Crawly is refers to Judith, therefore the word she can be categorized as third person deixis.

In data (4) the event happens in Nana's Mansion. The conversation is between Nana and Buster. The word "she" belongs to deixis. In data (1) she refers to Meena, in data (2) she refers to Meena, in data (3) she refers to Judith but in this conversation the word she is spoken by Buster is refers to Nana. The word she can be categorized as third person deixis.

Third Person Singular "HIM/HER"

Third person deixis HIM/HER they are classified as object pronoun. The analysis can be seen below.

(1) Miss Crawly : I have Judith from the bank.

Buster : Whaa, no no no, tell her, I'll call her back in the morning (00:30:33).

(2) Buster : I promised Nana something spectacular and this. It's gonna blow her away!

Miss Crawly : Oh yes (00:35:25).

In data (1) the conversation is between Buster and Miss Crawly. The event happens in Buster office. The word her belongs to deixis. The word her in the conversation above spoken by Buster. It is a deictic expression because it refers to a person that did not exist when the conversation begins, in the event pointed to a person other than the speaker and the hearer. The word her refers to Judith and the word her in 
the conversation above is an object pronoun. So it can be categorized as third person deixis.

In data (2) the conversation is between Buster and Miss Crawly. The event happens in theatre. The word her belongs to deixis. In data (1) her refers to Judith but in this case the word her in conversation above is spoken by Buster. It is a deictic expression because it refers to a person that did not exist when the conversation begins. The word her is object pronoun and it refers to Nana. It also can be categorized as third person deixis.

Besides third person deixis $H E R$, in data source it is also found third person deixis HER. The analysis can be seen below.

(1) Buster : Nana, please, just

listen to me for a second

Nana : No, absolutely

not

Eddie : Don't listen to

him, Nana. (00:41:17)

In data (1) the conversation is between Buster, Nana and Eddie. Buster and Eddie reveal Nana. The word "him" belongs to deixis. The word him in conversation above is spoken by Eddie. The word him found in the conversation is refers to Buster. So, the word "him" can be categorized into third person deixis.

Third Person Singular "HIS"

Third person deixis is classified as possessive adjective it is also found in the data, the analysis can be seen below.
(1) Buster
: Didn't you see
this? Huh? Look, it says I am a
"danger to society"
Gunter : Bah!
Buster : A deluded,
washed-up charlatan who never
had a hit in his career (00:59:16).
In data (1) the conversation is between Buster and Gunter. In the conversation above the word his is found in the conversation, the word his it refers to charlatan. And also it can be

classified as singular third person deixis.

b) Third Person Plural

Beside singular third person, plural third person is also found in the data source, it can be seen in the following discussion.

\section{Third Person Plural "THEY"}

Third person plural "they" it is classified as third person plural subject, the analysis can be seen below
(1) Cat
great?
: Aren't
they
Mike : What, are you
kidding me? It's like watching jello dancing around (00:49:52)
(2) Rosita : What's with the
face? You were great, they loved you!
Johnny : Yeah, thanks
Rosita (00:53:12)

In data (1) the conversation is between Cat and Mike. The word they in the conversation is spoken by Cat. The word they belongs to deixis. The word they is a deictic expression because it refers to people which is not exist in the conversation. The word they in the conversation refers to Rosita and Guntur on the live new broadcast, so the word they can be categorized as third person deixis.

In data (2) the conversation is between Rosita and Johnny. The word they belongs to deixis. The word they is a deictic expression because it refers to people which is not existing in the conversation. In data (1) they refers to Rosita and Gunter but in this case the word they is spoken by Rosita is refers to the audience, they are not exist in the speech event, therefore the word they in the conversation can be categorized as third person deixis.

\section{Time Deixis}

Time deixis is term used to point to a time. Deixis that shows the unit of time in the speech is called time deixis. In other word, time deixis refers to time relative to a temporal point, typically this point is the moment of utterance. The writer just found 
one data for time deixis. Time deixis now it is classified as adverb of time, it is also found in the data analysis can be seen in below.

(1) Buster : This stage is the battlefield. Your song is your weapon. Now, you only get one shot to blow that audience away, so choose carefully from the list of song I've selected for each of you Ash : Lance is an artist, but I wouldn't expect you to understand that $(00: 37: 19)$

(2) Big Daddy : Ha ha ha! We are set for life now, boys!

Big Daddy : What's going on? Where's Johnny?

Stan : He's not here (00:50:45)

(3) Buster : Listen, could you meet me on the corner of Dinsdale and Lemmington?

Eddie : What, now?
(00:28:34)

In data (1) the conversation is between Buster and Ash. The word now belongs to time deixis. The word now in the conversation above refers to the situation when the utterance is made, the word now means present time, so the word now is spoken by Buster refers to when he told Ash to choose the song that can make blow the audience when he made the utterance.

In data (2) the conversation is between Big Daddy and Stan.. Big Daddy finds the gang do no share his euphoria. The word now belongs to time deixis. The word now in the conversation above refers to the situation when the utterance is made, the word now means present time, so the word now is spoken by the speaker refers to Bid Daddy are set for a life when he made the utterance.

In data (3) the conversation is between Buster and Eddie. The word now belongs to time deixis.The word now in the conversation above refers to situation when the utterance is made, the word now in the conversation above refers to situation when the utterance is made, the word now means present time, so the word now is spoken by the speaker refers to Buster want Eddie pick him up at the place mention by Buster.

3. Deixis of Place

Deixis of place is relation to the location of some spaces between the speaker and the listener. Deixis of place is the location of people and things. Place deixis can be divided into two they are proximal (close to the speaker), and distal (which is sometimes close to the addressee).

In this part, the data is categories as proximal deixis; the writer just found one data for deixis of place and it can be seen in the following discussion. Proximal deixis of place here it is classified as adverb of place, it referred to something near the speaker, the data and analysis can be seen below.

(1) Eddie : What are you
doing here?
Buster : Eddie, you can't
come visit your Nana without
bringing her some flower
$(00: 45: 23)$

In data (1) the conversation is between Eddie and Buster. The word here is deixis of place. The word here in the conversation above is spoken by speaker, Eddie. The word here in the conversation indicates place deictic marker. Eddie is the speaker in the event. The information of place informs by the speaker before. The word here used to referent of specific place, the place which refers by the speaker is street near Nana's home.

\section{Social Deixis}

Social deixis is relation to the social information that encode within various expressions, such as relative social status and family. In social deixis, there are two types of it which is relational social deixis and absolute social deixis.

a. Relational Social Deixis

Relational social deixis means relation a social relationship between the speaker and an addressee, the analysis can be seen bellows.
a) Relational
Social
Deixis 
Relational social deixis grandpa, found in the data, relational social deixis referred to a status relation like family relation that related to the speaker, the data and analysis can be found in the analysis below

(1) Grandpa : So she's little shy, so what? If I had a voice like Meena's I'd be a superstar by now. Just singing

Meena : Sure you would,

Grandpa. Now blow out your candles (00:17:43)

In data (1) the conversation is between Grandpa and Meena. The word grandpa belongs to social deixis. The word grandpa in the conversation is spoken by Meena addressee to Grandpa. The word grandpa spoken by speaker refers to Meena's Grandpa; therefore the word grandpa can be categorized as relational social deixis

\section{b) Relational Social Deixis "MOMMY"}

Relational social deixis Mommy, found in the data, relational social deixis referred to a status relation like family relation that related to the speaker. The data and analysis can be seen below.

(1) Piglet : Mommy, where are you? Help! Help!

Rosita : Oh my gosh! Hold on! Mommy's here! (00:38:19)

In data (1) the conversation is between Piglet and Rosita. The word Mommy belongs to social deixis.The word "mommy" in the conversation spoken by Piglet, the utterance that spoken by Piglet addressee to Rosita. The word Mommy spoken by the speaker refers to Piglet's mommy and it is Rosita, therefore the word Mommy can be categorized as relation social deixis.

\section{Discourse Deixis}

Discourse deixis is the expression of the referent that is attached on the last, next on the current position of the discourse. Discourse deixis often in form of word for example: that and this. Other than that discourse deixis also can be as deictic reference to a portion of a discourse relative o the speaker current location for example : above, below, last, next and previous.

a) Discourse Deixis of "THIS"

Discourse deixis of this, it is classified as demonstrative, it refers to the context in the utterance, the analysis can be seen in below.

(1) Ash : I am not singing this

Buster : What's not to

like? You're a female and you're a teenager. This song was made for you $(00: 25: 32)$

In data (1) the conversation is between Ash and Buster. Buster plays intro to "Call Me Maybe" by Carly Rae Japsen. The word this belongs to discourse deixis. In the conversation (1), the word this spoken by Ash, denoted a deictic expression. The information from the deictic element refers to Ash who does not want to sing Call Me Maybe. The word this is not only used to pointing something but in the dialogue above the word this refers to action that states by the speaker, therefore it can be classified as discourse deixis.

b) Discourse Deixis of "THAT"

Discourse deixis of that it is classified as demonstrative, it is also found in the data. It is referred to the context in the utterance, the analysis can be seen below.

$\begin{array}{ll}\text { (1) Ash } & \text { : Uh, yeah. Do you } \\ \text { like it? } & \text { : Are you lidding? } \\ \text { Buster } & \end{array}$

It's fantastic! You gotta sing that today! (00:43:54)

In data (1) the conversation is between Ash and Buster. The word that belongs to discourse deixis. In the conversation above the word that is also found and it spoken by Buster, the word that in the conversation above is not used to referring something but it used to refer the information uttered by Ash, therefore it can be categorized as discourse deixis. 


\section{CONCLUSION}

After analyzing all data found in movie script especially about deixis. In this chapter the writer can conclude some points. The point is about deixis relation with person, time, discourse, social and place. For feting the conclusion, let us see explanation below.

1. The person deixis found in the utterance in this movie script are $I, m e$, my, him, she, her, his, they and we. From the entire of person deixis found in this movie script, the person deixis $I$ is the dominant used. It can be explain that person deixis $I$ indicates to Buster. So, he is the main character in this movie. Person deixis is used in the utterance in this novel aimed to know who are the speaker and the addressee and other significant participants in the speech situation that is known as third person.

2. The place deixis or spatial deixis found in the movie script is here. The writer just found one data for place deixis. Place deixis used in the utterance in this movie script is purposed to know how distance the speech situation between the participants happened.

3. The time deixis or temporal deixis in this movie script is now. The writer just found one data for time deixis. Time deixis used in this movie script is meant to know the moment of the utterance as a reference point of the participan's conversation that is happened.

4. The discourse deixis in this movie script are this and that. Discourse deixis used in this movie script is meant to know what is being or has been talked by the participants of the conversation or what will be talked by the participants of the conversation

5. The social deixis is used to code social relationship between the speaker and the addressee, relational social is also can be found in the data, relational social deixis means there is some relation between the speaker and addressee such as Grandpa and Mommy.

\section{REFERENCES}

Kreidler, C. (1998). Introducing English Semantics. Routledge.

Leech, G. (1981). Semantics. Penguin Books Ltd.

Levinson, S. C. (1983). Pragmatics. Cambridge University Press.

Lyons, J. (1977). Semantics. Cambridge University Press.

Saeed, J. I. (2000). Semantics. Blackwell.

Sudaryanto. (1986). Metode linguistik. Gadjah Mada University Press.

Yule, G. (1995). Pragmatics. Oxford University Press. 